\title{
Peningkatan Aktivitas dan Hasil Belajar IPS Melalui Pembelajaran Model Inkuiri Sosial
}

\author{
Ahmad Taufik, M.Pd \\ SMPN 2 Jogoroto Jombang \\ Email: a.taufik68@gmail.com
}

\begin{abstract}
Abstrak
Proses pembelajaran IPS di sekolah selama ini lebih ditekankan kepada penguasaan materi sebanyak mungkin sehingga proses pembelajaran bersifat kaku dan terpusat pada satu arah. Kesempatan bagi siswa untuk belajar lebih aktif dengan melakukan eksplorasi terhadap materi yang diajarkan terabaikan. Kegiatan belajar lebih ditandai dengan budaya hafalan daripada proses berpikir. Pembiasaan ini mengakibatkan siswa kurang mampu menjawab pertanyaan berbasis masalah yang diajukan guru. Hasil pengamatan di lapangan, pada waktu siswa dibelajarkan dengan menggunakan metode diskusi teman sebangku begitu kesulitan dalam menjawab pertanyaan yang diawali dengan kalimat tanya mengapa atau bagaimana. Hal ini diperkuat dengan hasil tes siswa 70,2, dibawah KKM yang ditentukan dengan prosentase keberhasilan 45,2\%, masih jauh dari ketuntasan klasikal 85\%. Berdasarkan kenyataan tersebut, maka peneliti mencoba menggunakan pembelajaran model inkuiri sosial untuk meningkatkan kemampuan siswa dalam menjawab pertanyaan berbasis masalah. Tujuan penelitian ini adalah untuk meningkatkan aktivitas dan hasil belajar siswa dalam menjawab pertanyaan berbasis masalah melalui penemuan (inkuiri sosial). Model inkuiri sosial adalah proses pembelajaran dimana siswa tidak hanya berperan sebagai penerima pelajaran melalui penjelasan guru secara verbal, tetapi mereka berperan untuk menemukan sendiri inti dari materi pelajaran itu. Berdasarkan hasil tes pasca pembelajaran inkuiri sosial diperoleh nilai rata-rata kelas siklus I adalah 74,9 (71\%) dan siklus II yaitu 85,2 (93,6\%). Berdasarkan hasil penelitian tersebut, maka disimpulkan pembelajaran model inkuiri sosial dapat meningkatkan aktivitas dan hasil belajar siswa SMPN 2 Jogoroto Jombang. Model inkuiri sosial dapat digunakan untuk meningkatkan hasil belajar siswa.
\end{abstract}

Kata Kunci : model inkuiri sosial, aktivitas dan hasil belajar, IPS 


\section{PENDAHULUAN}

Proses pembelajaran IPS di sekolah selama ini lebih ditekankan kepada penguasaan materi sebanyak mungkin sehingga proses belajar bersifat kaku dan terpusat pada satu arah, tidak memberikan kesempatan bagi siswa untuk belajar lebih aktif dengan melakukan eksplorasi terhadap materi yang diajarkan. Kegiatan belajar lebih ditandai dengan budaya hafalan daripada berpikir, akibatnya siswa menganggap materi pelajaran IPS hanya untuk dihafalkan. Kenyataan ini menyebabkan siswa tidak mampu menerapkan konsep dasar dari materi IPS dalam kondisi kehidupan mereka.

Pembelajaran IPS di sekolah dipengaruhi oleh kebutuhan untuk memperoleh hasil evaluasi akhir yang memuaskan. Hal ini bukan saja berdampak pada perilaku siswa yang semata-mata mempelajari IPS dengan menghafal saja, tetapi juga pada metode pengajaran guru, kebijakan pimpinan sekolah, dan harapan orang tua terhadap hasil akhir yang dinilai secara kuantitatif saja. Dalam kondisi seperti ini strategi pembelajaran yang digunakan yaitu expository, biasanya hanya berupa ceramah yang berjalan satu arah (pendekatan teacher center) dan menekankan pada penguasaan materi sebanyak-banyaknya.

Untuk meningkatkan kualitas proses dan hasil belajar, para ahli pembelajaran telah menyarankan penggunaan paradigma konstruktivistik. Dengan perubahan paradigma belajar tersebut terjadi perubahan pusat (fokus) pembelajaran dari belajar berpusat pada guru kepada belajar berpusat pada siswa. Proses pembelajaran yang dilakukan harus interaktif, inspiratif, menyenangkan, menantang, memotivasi peserta didik untuk berpartisipasi aktif, serta memberikan ruang yang cukup tinggi bagi prakarsa, kreativitas dan kemandirian sesuai dengan bakat, minat dan perkembangan anak didik (PP 19/2005, pasal 19 ayat 1). Untuk mencapai tujuan tersebut guru hendaknya menerapkan model-model pembelajaran yang inovatif.

Berdasarkan hasil pengamatan peneliti pada saat pembelajaran menggunakan metode diskusi teman sebangku, sebagian besar siswa mengalami kesulitan menjawab soal yang diawali kata jelaskan, mengapa dan bagaimana (pertanyaan berbasis masalah), kegiatan diskusi teman sebangku siswa putri terlihat lebih aktif daripada siswa laki-laki, siswa cenderung pasif berdiskusi karena terbatasnya sumber belajar yang mereka miliki.

Berdasarkan identifikasi masalah-masalah di atas, masalah yang paling penting dan mendesak untuk segera dipecahkan adalah rendahnya kemampuan siswa dalam menjawab soal yang diawali dengan kalimat tanya jelaskan, mengapa dan bagaimana (pertanyaan berbasis masalah). Berdasarkan hasil pengamatan peneliti, penyebabnya adalah karena siswa kurang terbiasa diajak berfikir ilmiah (saintifik), guru kurang tepat dalam pemilihan metode atau model pembelajaran. Untuk memecahkan permasalahan rendahnya hasil belajar tentang kemampuan siswa menjawab pertanyaan berbasis masalah, maka peneliti mencoba menggunakan pembelajaran model Inkuiri Sosial.

Inkuiri Sosial merupakan salah satu strategi pembelajaran yang cocok dengan pembelajaran IPS, dimana strategi tersebut membantu siswa untuk berfikir kritis dan kreatif sesuai dengan tujuan pembelajaran IPS. Ditinjau dari segi ilmu pengetahuan 
khususnya mengenai prinsip-prinsip penelitian ilmiah (saintifik), strategi Inkuiri sosial sangat cocok untuk penelaahan gejala-gejala sosial. Inkuiri sosial adalah strategi belajar yang menekankan kepada pengalaman siswa untuk memecahkan masalah sosial melalui langkah-langkah dan prosedur pemecahan masalah (Isjoni,2007).

Temuan penelitian menunjukkan bahwa adanya perbedaan hasil belajar antara siswa yang menggunakan model pembelajaran inkuiri dan siswa yang menggunakan model pembelajaran konvensional. Hasil belajar siswa yang mengikuti pembelajaran inkuiri lebih tinggi daripada siswa yang mengikuti pembelajaran konvensional (Djamani, 2009) dalam Eri Kusumawati, 2011).

Dengan pembelajaran inkuiri sosial siswa diberi pengalaman yang memadai bagaimana caranya memecahkan persoalan-persoalan yang muncul di masyarakat. Melalui pengalaman itulah setiap individu akan dapat membangun pengetahuan yang berguna bagi diri dan masyarakatnya. Inkuiri sosial dapat dipandang sebagai suatu strategi pembelajaran yang berorientasi kepada pengalaman siswa.

\section{METODE PENELITIAN}

Jenis Penelitian Tindakan Kelas (Classroom Action Researh) ini menggunakan teknik purposive sampling atau sampel bertujuan yaitu mengambil subyek yang didasarkan atas tujuan tertentu (2006:39). Peneliti adalah guru dari sekolah tersebut, maka tujuan tertentu (purposive samplin) yaitu untuk memperbaiki proses dan hasil pembelajaran. Penelitian tindakan kelas ini menggunakan pola Hopkins dengan tiga siklus yang setiap siklus terdiri atas; (1) perencanaan, (2) tindakan dan pengamatan (observasi) dan (3) refleksi. Jika pada siklus ke dua telah tercapai ketuntasan belajar maka penelitian dianggap telah selesai.

Dalam mengumpulkan data, metode yang digunakan meliputi metode pengamatan (observasi), dokumentasi dan wawancara. Metode pengamatan digunakan untuk mengamati pembelajaran. Metode dokumentasi digunakan untuk mengumpulkan dokumen pembelajaran antara lain berupa RPP, naskah ulangan harian, tugas rumah, jurnal pembelajaran, daftar nilai, dan foto-foto kegiatan pembelajaran. Metode wawancara digunakan untuk mengetahui respon peserta didik berkaitan dengan penerapan model inquiry learning. Dalam melaksanakan metode pengamatan dan wawancara, peneliti dibantu seorang guru pendamping.

\section{HASIL DAN PEMBAHASAN}

\section{Pembelajaran Model Inkuri Sosial}

Pada awalnya pembelajaran inkuiri banyak diterapkan dalam ilmu-ilmu alam (natural science), kemudian para ahli pendidikan ilmu sosial berusaha mengadopsinya 
sehingga muncullah pembelajaran inkuiri sosial. Menurut Bruce Joyce (dalam Akhmad Sudrajat), inkuiri sosial merupakan strategi pembelajaran dari kelompok sosial (social family) subkelompok konsep masyarakat (concept of society). Subkelompok ini didasarkan pada asumsi bahwa metode pendidikan bertujuan untuk mengembangkan anggota masyarakat ideal yang dapat hidup dan dapat mempertinggi kualitas kehidupan masyarakat. Oleh karena itu, siswa harus diberi pengalaman yang memadai bagaimana caranya memecahkan persoalan-persoalan yang muncul di masyarakat.

Ada tiga karakteristik pengembangan strategi inkuiri sosial: (1) adanya aspek (masalah) sosial dalam kelas yang dianggap penting dan dapat mendorong terciptanya diskusi kelas; (2) adanya rumusan hipotesis sebagai fokus untuk inkuiri; dan (3) penggunaan fakta sebagai pengujian hipotesis.

\section{Tahapan Pembelajaran Inkuiri Sosial}

Menurut Wina Sanjaya (2007) (dalam Akhmad Sudrajat) tahapan proses pembelajaran inkuiri sosial dapat dilaksanakan dengan mengikuti langkah-langkah sebagai berikut:

\section{a. Tahap Orientasi}

Langkah yang pertama ini dimaksudkan untuk membina suasana/iklim pembelajaran yang responsif. Pada langkah ini guru mengondisikan agar siswa siap melaksanakan proses pembelajaran, guru merangsang dan mengajak siswa untuk berpikir memecahkan masalah. Beberapa hal yang dapat dilakukan dalam tahapan orientasi ini adalah: (a) menjelaskan topik, tujuan dan hasil belajar yang diharapkan dapat dicapai oleh siswa.; (b) menjelaskan pokok-pokok kegiatan yang harus dilakukan oleh siswa untuk mencapai tujuan; dan (c) menjelaskan pentingnya topik dan kegiatan belajar.

\section{b. Tahap Merumuskan Masalah}

Merumuskan masalah merupakan langkah membawa siswa pada suatu persoalan yang mengandung teka-teki. Persoalan yang disajikan adalah persoalan yang menantang siswa untuk berpikir memecahkan teka-teki itu. Poses mencari jawaban sangat penting dalam strategi inkuiri, oleh sebab itu melalul proses tersebut siswa akan memperoleh pengalaman yang sangat berharga sebagai upaya mengembangkan mental melalui proses berpikir. Beberapa hal yang harus diperhatikan dalam merumuskan masalah, diantaranya: (a) masalah hendaknya dirumuskan sendiri oleh siswa, (b) masalah yang dikaji adalah masalah yang mengandung teka-teki yang jawabannya pasti.; dan (c) konsep-konsep dalam masalah adalah konsep-konsep yang sudah diketahui terlebih dahulu oleh siswa.

\section{c. Tahap Merumuskan Hipotesis}

Hipotesis adalah jawaban sementara dari suatu permasalahan yang sedang dikaji. Sebagai jawaban sementara, hipotesis perlu diuji kebenarannya. Kemampuan atau potensi individu untuk berpikir pada dasarnya sudah dimiliki sejak individu itu lahir. Potensi berpikir itu dimulai dari kemampuan setiap individu untuk menebak atau mengira-ngira (berhipotesis) dari suatu permasalahan. 


\section{d. Tahap Mengumpulkan Data}

Mengumpulkan data adalah aktivitas menjaring informasi yang dibutuhkan untuk menguji hipotesis yang diajukan. Dalam strategi pembelajaran inkuiri, mengumpulkan data merupakan proses mental yang sangat penting dalam pengembangan intelektual. Proses pengumpulan data bukan hanya memerlukan motivasi yang kuat dalam belajar, akan tetapi juga membutuhkan ketekunan dan kemampuan menggunakan potensi berpikirnya.

\section{e. Tahap Menguji Hipotesis}

Proses menentukan jawaban yang dianggap diterima sesuai dengan data atau informasi yang diperoleh berdasarkan pengumpulan data. Yang terpenting dalam menguji bipotesis adalah mencari tingkat keyakinan siswa atas jawaban yang diberikan. Disamping itu, menguji hipotesis juga berarti mengembangkan kemampuan berpikir rasional. Artinya, kebenaran jawaban yang diberikan bukan hanya berdasarkan argumentasi, akan tetapi harus didukung oleh data yang ditemukan dan dapat dipertanggungjawabkan.

\section{f. Tahap Merumuskan kesimpulan}

Proses mendeskripsikan temuan yang diperoleh berdasarkan hasil pengujian hipotesis. Merumuskan kesimpulan merupakan gongnya dalam proses pembelajaran. Karena itu, untuk mencapai kesimpulan yang akurat sebaiknya guru mampu menunjukkan pada siswa data mana yang relevan.

Dalam penelitian ini peneliti mengadaptasi dari langkah-langkah Sanjaya dan Yuliono dalam model inkuiri sebagai berikut : (1) guru melakukan apersepsi, (2) guru meyampaikan kompetensi dasar dan indikator pembelajaran, (3) guru menyampaikan materi yang berkaitan dengan konsep-konsep sosiologi, (4) guru menyiapkan LKS, artikel yang mengandung tema diskusi, (5) Guru membagi peserta didik menjadi enam kelompok dimana tiap kelompok terdiri dari 5/6 siswa, (6) guru meminta peserta didik mendiskusikan jawaban sementara(hipotesis) dari permasalahan yang telah diberikan guru, (7) siswa disuruh brosing internet atau mengumpulkan data untuk mencari informasi yang berkaitan dengan permasalahan yang harus mereka pecahkan (8) siswa membandingkan hipotesis hasil pemikiran sendiri dengan hasil mencari dari sumber belajar lain (9) setiap kelompok mempresentasikan hasil diskusi yang telah mereka buat di depan kelas, (10) refleksi dan penguatan materi temuan siswa oleh guru .

\section{Hasil Belajar}

Hasil belajar adalah penguasaan pengetahuan atau keterampilan yang dikembangkan oleh mata pelajaran, lazimnya ditunjukkan dengan nilai tes atau angka nilai yang diberikan oleh guru.

Hasil belajar adalah kemampuan-kemampuan yang dimiliki siswa setelah ia menerima pengalaman belajarnya (Sudjana,2008). Hasil belajar juga dapat didefinisikan sebagai pemahaman dan penguasaan pengetahuan, keterampilan dan nilai sikap siswa setelah mengalami proses pembelajaran. Hasil belajar ini diukur dengan nilai yang diperoleh siswa. 
Hasil belajar dapat diklasifikasi menjadi tiga ranah yaitu ranah kognitif, ranah sikap dan ranah psikomotorik. Ranah kognitif yaitu berkenaan dengan pengukuran hasil belajar intelektual yang terdiri dari enam aspek yakni pengetahuan, pemahaman, penerapan, analisis, sintesis, dan penilaian. Ketiga ranah tersebut menjadi obyek penilaian dalam hasil belajar (Bloom (dalam Degeng, 2005).

\section{Ilmu Pengetahuan Sosial}

\section{a. Ruang lingkup IPS}

IPS menurut Peraturan Menteri Pendidikan Nasional nomor 22 tahun 2006 tentang Standar Isi, mengkaji seperangkat peristiwa, fakta, konsep, dan generalisasi yang berkaitan dengan isu sosial. IPS adalah suatu penyederhanaan disiplin ilmu-ilmu sosial, ideologi Negara dan disiplin ilmu lainnya serta masalah-masalah sosial terkait, yang diorganisasikan dan disajikan secara ilmiah dan psikologis untuk tujuan pendidikan pada tingkat pendidikan dasar dan menengah (Somantri, 2001).

\section{b. Tujuan Mata pelajaran IPS}

Adapun tujuan mata pelajaran IPS di SMP adalah: (1) mengenal konsepkonsep yang berkaitan dengan kehidupan masyarakat dan lingkungannya; (2) memiliki kemampuan dasar untuk berpikir logis dan kritis, rasa ingin tahu, inkuiri, memecahkan masalah, dan keterampilan dalam kehidupan sosial; (3) memiliki komitmen dan kesadaran terhadap nilai-nilai sosial dan kemanusiaan; dan (4) memiliki kemampuan berkomunikasi, bekerjasama dan berkompetisi dalam masyarakat yang majemuk, di tingkat lokal, nasional, dan global.

Tujuan Pendidikan IPS pada tingkat sekolah adalah Menekankan tumbuhnya nilai kewarganegaraan, moral, ideologi negara dan agama, kedua menekankan pada isi dan metode berfikir ilmuwan dan yang terakhir menekankan reflective inquiry (Somantri, 2001).

Dalam penelitian ini, hasil pembelajaran yang ingin dilihat adalah hasil belajar tentang kemampuan siswa dalam menjawab pertanyaan-pertanyaan berbasis masalah. Materi-materi pembelajaran tersebut berkaitan dengan tujuan-tujuan pembelajaran yang ingin dicapai dalam pembelajaran IPS.

Berdasarkan hasil penelitian penerapan pembelajaran model inkuiri sosial memberikan hasil belajar yang lebih tinggi, hal ini terlihat dari hasil tes nilai rata-rata kelas pra siklus $70,2(45,2 \%)$ meningkat menjadi 74,9 (71\%) pada siklus I, dan meningkat lagi menjadi $85,2(93,6 \%)$ pada siklus II.

Hasil belajar siswa meningkat dikarenakan 1) siswa lebih aktif dalam menggali informasi, 2) siswa dapat menemukan sendiri (inkuiri) jawaban atas pertanyaan yang telah dirumuskan, dan 3) peneliti dapat berperan aktif dalam membimbing siswa menggali informasi untuk menemukan jawaban atas pertanyaan yang telah dirumuskan. Temuan ini sejalan dengan hasil penelitian bahwa salah satu manfaat yang dapat diperoleh dari model inkuiri adalah munculnya sikap keilmiahan siswa, misalnya sikap objektif, rasa ingin tahu yang tinggi, dan berpikir kritis. Dengan sikap keilmiahan yang baik, konsep-konsep dalam ilmu pengetahuan sosial lebih mudah dipahami oleh siswa. 
Begitu juga, dengan motivasi belajar yang tinggi, kegiatan pembelajaran IPS juga menjadi lebih mudah mencapai tujuannya (Haury, 1993).

Keuntungan atau keunggulan-keunggulan pembelajaran dengan model inkuiri adalah sebagai berikut: (a) pembelajaran inqury meningkatkan potensi intelektual siswa. Hal ini terjadi karena siswa diberikan kesempatan untuk mencari dan menemukan sendiri jawaban permasalahan yang diberikan, dan hal-hal lainnya yang berkaitan dengan pengamatan dan pengalaman sendiri, (b) siswa yang telah berhasil menemukan sendiri sehingga dapat memecahkan masalah yang ada akan meningkatkan kepuasan intelektualnya yang justru datang dari dalam diri siswa, (c) siswa dapat belajar bagaimana melakukan penemuan, hanya melalui proses melakukan penemuan itu sendiri, (d) belajar melalui inkuiri dapat memperpanjang proses ingatan atau konsep yang telah dipahami siswa lebih lama dapat diingat, (e) belajar melalui inkuiri, siswa dapat memahami konsep-konsep dan ide-idenya dengan lebih baik, (f) pengajaran menjadi lebih terpusat pada siswa, (g) proses pembelajaran inkuiri dapat membentuk dan mengembangkan konsep diri, (h) melalui pembelajaran inkuiri dimungkinkan tingkat harapan bertambah, (i) pembelajaran inkuiri dapat mengembangkan bakat, diantaranya bakat akademik (Bruner (1978) (dalam Eri Kusumawati, 2011).

Pengetahuan yang diperoleh dengan belajar model inkuiri menunjukkan beberapa kebaikan yaitu: (1) pengetahuan itu bertahan lama atau lama dapat diingat, atau lebih mudah diingat bila dibandingkan dengan pengetahuan yang dipelajari dengan cara-cara lain. ,(2) hasil belajar penemuan mempunyai efek transfer yang lebih baik daripada hasil belajar lainnya. Dengan kata lain, konsep-konsep dan prinsip-prinsip yang dijadikan milik kognitif seseorang lebih mudah diterapkan pada situasi-situasi baru, (3) secara menyeluruh belajar model inkuiri meningkatkan penalaran siswa dan kemampuan untuk berpikir secara bebas.

Beberapa hal yang menjadi ciri utama model pembelajaran inquiry. Pertama, model inquiry menekankan kepada aktifitas siswa secara maksimal untuk mencari dan menemukan, artinya pendekatan inquiry menempatkan siswa sebagai subjek belajar. Dalam proses pembelajaran, siswa tidak hanya berperan sebagai penerima pelajaran melalui penjelasan guru secara verbal, tetapi mereka berperan untuk menemukan sendiri inti dari materi pelajaran itu sendiri. Kedua, seluruh aktivitas yang dilakukan siswa diarahkan untuk mencari dan menemukan sendiri dari sesuatu yang dipertanyakan, sehingga diharapkan dapat menumbuhkan sikap percaya diri (self belief). Artinya dalam pendekatan inquiry menempatkan guru bukan sebagai sumber belajar, akan tetapi sebagai fasilitator dan motivator belajar siswa. Aktvitas pembelajaran biasanya dilakukan melalui proses tanya jawab antara guru dan siswa, sehingga kemampuan guru dalam menggunakan teknik bertanya merupakan syarat utama dalam melakukan inquiry. Ketiga, tujuan dari penggunaan model pembelajaran inquiry adalah mengembangkan kemampuan intelektual sebagai bagian dari proses mental, akibatnya dalam pembelajaran inquiry siswa tidak hanya dituntut agar menguasai pelajaran, akan tetapi bagaimana mereka dapat menggunakan potensi yang dimilikinya (Sanjaya, 2008) 
Beberapa kelebihan pembelajaran dengan model inkuiri diantaranya adalah ; (1) pembelajaran menjadi terpusat pada siswa ( student contered), dimana siswa tidak hanya belajar menemukan konsep dan prinsip-prinsip tetapi ia juga mengalami proses belajar tentang tanggung jawab dan komunikasi sosial, (2) dapat membentuk dan mengembangkan konsep dan sikap yang ada pada diri siswa, (3) tingkat pengharapan siswa bertambah yaitu siswa mempunyai ide tertentu tentang bagaimana dapat menyelesaikan suatu tugas dengan cara mereka sendiri, (4) proses belajar inkuiri dapat menghindarkan siswa dari cara-cara belajar dengan cara menghafal, 5) proses belajar inkuiri memberikan waktu bagi siswa untuk mengasimilasi dan mengakomodasi informasi (Syah, 2003).

Keuntungan belajar dengan model inkuiri ini adalah (1) adanya kemungkinan siswa dalam memecahkan masalah open ended dan (2) mempunyai alternatif pemecahan masalah lebih dari satu cara, karena tergantung bagaimana cara mereka mengkonstruksi jawabannya sendiri. Selain itu,(3) ada kemungkinan siswa menemukan cara dan solusi yang baru atau belum pernah ditemukan oleh orang lain dari masalah, (Sanjaya, 2008).

Berdasarkan pengalaman peneliti mengajar menggunakan model inkuiri sosial ada peningkatan aktivitas selama berlangsungnya kegiatan belajar mengajar yaitu (1) semua siswa lebih antusias dan aktif dalam menjawab LKS, (2) semua kelompok sangat antusias dalam menggali informasi secara langsung dari responden, terutama yang kebagian wawancara diluar sekolah, (3) aktivitas siswa dalam sesi presentasi meningkat sejalan meningkatnya kemampuan siswa berinkuiri. Aktivitas siswa bertanya dari $25 \%$ pada sisklus I meningkat menjadi $64,5 \%$ pada siklus II, jumlah siswa menjawab16\% meningkat menjadi 32,3\%, dan aktivitas siswa dalam menanggapi dari 6,5\% pada sisklus I meningkat menjadi 25,8 pada siklus II. dan (4) Hasil belajar siswa sudah mencapai standar nilai KKM dengan ketuntasan klasikal diatas 85\%, (5) Sedangkan tanggapan siswa tentang pembelajaran model inkuiri sosial $100 \%$ membuat siswa merasa senang, merasa bisa, antusias,tahu cara memanfaatkan sumber belajar, dan membiasakan berfikir kritis dalam menjawab pertanyaan berbasis Masalah

\section{KESIMPULAN}

Berdasarkan diskripsi, analis data, temuan penelitian, dan pembahasan maka dapat diambil kesimpulan bahwa Penerapan model inkuiri sosial dapat meningkatkan aktivitas dan hasil belajar siswa dalam pembelajaran IPS. Hal ini dibuktikan dengan meningkatnya kemampuan siswa dalam menjawab pertanyaan berbasis masalah, dengan prosentase keberhasilan 93,6\% diatas ketuntasan klasikal 85\%.

Guru IPS dalam rangka menyambut implementasi kurikulum 2013 disarankan menggunakan pembelajaran model inkuiri sosial dalam kegiatan pembelajaran untuk meningkatkan kemampuan berfikir kritis siswa. Pembelajaran model inkuiri sosial menuntut keaktifan dan kemandirian siswa dalam belajar, sehingga kedua hal tersebut dikondisikan terlebih dahulu agar penerapan pembelajaran model inkuiri sosial dapat berjalan dengan lancar sesuai rencana pembelajaran yang telah ditetapkan. 


\section{DAFTAR PUSTAKA}

Banks, James. A. 1990. Teaching Strategies For The Social Studies (Inquiry, Valuing, And Decision Making). Longman. New York and London

Degeng, I Nyoman Sudana.2008. Teori Pembelajaran 2 ( terapan ). Hand Book . Program Pasca Sarjana. Universitas Kanjuruhan Malang.

Degeng, I Nyoman Sudana.2005. Teori Pembelajaran 1: Taksonomi variabel. Hand Book . Program Pasca Sarjana. Universitas Kanjuruhan Malang

Eri Kusumawati dan Rini Wartiningsih (2011).Upaya Meningkatkan hasil Belajar Mengidentifikasikan Sifat-sifat Benda Cair Melalui Pembelajaran Model Inqury bagi Siswa Kelas IV SDN Jatikalang I Krian Sidoarjo. Penelitian Tindakan Kelas tidak diterbitkan.

Haury .2000. Teaching Science.Through Inquiry.Colombus,OH:ERIC Clearing House of Scince,Mathematic, and Environment Education

Isjoni. 2007. Integrated Learning (Pendekatan Pembelajaran IPS Di Pendidikan Dasar). Penerbit Falah Production. Bandung

Sanjaya \& Wina. . (2008). Strategi Pembelajaran Berorientasi Standar Proses Pendidikan. Kencana Prenada Media Group. Jakarta

Somantri, Numan. 2001. Menggagas Pembaharuan Pendidikan IPS. Remaja Rosdakarya. Bandung

Sudjana, Nana. 2008. Penelitian Hasil Belajar Mengajar. Bandung: Rosda Karya.

Syah,M (2003).Psikologi Pendidikan.Jakarta.Rajawali Pers.

Suhardjono. 2011. Penelitian Tindakan Kelas dan Tindakan Sekolah, Malang. Cakrawala Indonesia dan LP3 Universitas Negeri Malang.

Yulianto, dkk (2008). Model-Model Pembelajaran Inovatif. Pusat Penerbitan Universitas Negeri Surabaya

http://akhmadsudrajat.wordpress.com/2011/01/30/pembelajaran-inkuiri-sosial/ diakses 2 Januari 2015) 